\title{
$\beta$-hexosaminidase splice site mutation has a high frequency among non-Jewish Tay-Sachs disease carriers from the British Isles
}

\author{
Eleanor C Landels, Peter M Green, Ian H Ellis, Anthony H Fensom, Martin Bobrow
}

\begin{abstract}
In the course of defining mutations causing Tay-Sachs disease (TSD) in non-Jewish patients and carriers from the British Isles, we identified a guanine to adenine change (also previously described) in the obligatory GT sequence of the donor splice site at the 5 ' end of intron 9 of the hexosaminidase $\alpha$ peptide gene. Of 24 unrelated mutant chromosomes from 20 non-Jewish subjects (15 TSD carriers, four TSD patients, and one TSD fetus), five had mutations common in the Ashkenazi Jewish community, and 10 had the intron 9 splice site mutation. This is an unexpected result considering the diverse origin of the population of the British Isles. This mutation was not found in 28 control UK subjects or 11 Jewish carriers of known TSD mutations. Before attempting detection of unknown mutations, non-Jewish TSD carriers from the British Isles should be screened for the intron 9 donor splice site mutation as well as those mutations which predominate in the Jewish community.
\end{abstract}

Tay-Sachs disease (TSD) is one of the $G_{M 2}$ gangliosidoses, a group of neurodegenerative disorders of autosomal recessive inheritance. In the 'classic' infantile form of TSD, onset of symptoms occurs at about 6 months and death by 4 years of age. The symptoms are caused by accumulation of the ganglioside $G_{M 2}$ in neuronal cells owing to deficient activity of the lysosomal enzyme which metabolises it, $\beta$ hexosaminidase A (hex A). ${ }^{1}$ The frequency of TSD carriers in the general population is approximately $1 / 200$, but is much higher in certain ethnic groups (for example, 1/27 in Ashkenazi Jews), and carrier screening programmes involving assay of serum hex $A$ have been implemented in order to reduce incidence of the disease.

Hex $A$ is composed of $\alpha$ and $\beta$ peptide chains, coded for by genes on chromosomes 15 and 5, respectively; mutations in the $\alpha$ peptide (HEXA) gene are the cause of TSD. This gene has been cloned ${ }^{23}$ and several mutations causing TSD have been described. The first of these were found in ethnic groups having a high incidence of TSD, namely the FrenchCanadian population (nearly $3 \%$ of whom are carriers, predominantly of a $7.6 \mathrm{~kb}$ deletion), ${ }^{45}$ and the Ashkenazi Jews (3\% of whom are TSD carriers, predominantly of a 4 base pair insertion in exon $11^{6}$ and a mutation of the intron 12 donor splice site $\left.^{7-9}\right)$. More recently, a phenylalanine deletion has been described in five out of eight obligate TSD carriers from the Moroccan Jewish population. ${ }^{10}$ Many different mutations, all individually rare, have also been described in patients from low incidence populations, some of which have been reviewed by Neufeld. ${ }^{11}$

We have previously assessed the frequency of known TSD causing mutations in $41 \mathrm{UK}$ Ashkenazi Jewish TSD carriers ${ }^{12}$; 33 had the exon 11 insert mutation and eight had the intron 12 splice site mutation. In the present study we have attempted to identify the mutations in non-Jewish TSD patients and carriers from the UK and Eire using amplification by polymerase chain reaction (PCR) ${ }^{13}$ and chemical mismatch detection ${ }^{14} 15$ followed by direct sequencing ${ }^{16}$ of amplified products. These techniques have already been used successfully to detect new mutations causing other genetic diseases, for example haemophilia $A^{17}$ and $B^{15}$ and Duchenne muscular dystrophy, ${ }^{18}$ and more recently Tay-Sachs disease. ${ }^{19}$

\section{Methods}

The diagnosis of TSD, or carrier status, was established by enzyme assay of fibroblast samples, chorionic villi sample and/or serum and leucocyte samples using previously described methods. ${ }^{20}$ Genomic DNA of TSD patients, carriers, and 28 UK non-Jewish control subjects was extracted from EDTA blood, fibroblasts, or from cultured chorionic villi cells using established techniques. ${ }^{21}$ RNA was extracted from fibroblasts or EDTA blood using the acid-guanidinium thiocyanatephenol-chloroform method $^{22}$ modified (by using sodium acetate at $\mathrm{pH} 5 \cdot 2$ instead of pH 4) to coprecipitate DNA with the RNA.

All of the TSD carriers (as defined by enzyme assay) were tested for the exon 11 insert and intron 12 donor splice site mutations (which predominate in Jewish TSD carriers) using methods described elsewhere ${ }^{12}$; subjects negative for these were screened for unknown mutations using chemical mismatch detection. The HEXA gene was amplified from genomic DNA by PCR in nine sections from exon 2 to the $3^{\prime}$ untranslated region with primers designed from the published cDNA sequence ${ }^{2}$ (sequences available on request) and synthesised using a PCR-mate DNA synthesiser (Applied Biosystems). Approximately $50 \mathrm{ng}$ genomic DNA were subjected to PCR amplification in a $50 \mu \mathrm{l}$ reaction volume containing $1 \times$ PCR buffer $(67 \mathrm{mmol} / 1$ Tris- $\mathrm{HCl}, \mathrm{pH} 8.8$, 
Table 1 Results of screening for the intron 9 splice site mutation and the exon 11 insert and intron 12 splice site mutations.

\begin{tabular}{|c|c|c|c|c|}
\hline \multirow{3}{*}{$\begin{array}{l}\text { No of } \\
\text { unrelated } \\
\text { chromosomes }\end{array}$} & \multirow[b]{3}{*}{ Source } & \multicolumn{3}{|c|}{ No positive for mutation } \\
\hline & & \multirow[t]{2}{*}{ Intron 9} & \multicolumn{2}{|c|}{ 'Jewish' mutations } \\
\hline & & & Exon 11 & Intron 12 \\
\hline $1 !$ & $\begin{array}{l}\text { Obligate carrier parents } \\
(\mathrm{n}=11)\end{array}$ & 4 & 4 & 0 \\
\hline 1 & $\begin{array}{l}\text { Carrier on enzyme screening } \\
\text { plus family history }(n=1)\end{array}$ & 0 & 0 & 0 \\
\hline 3 & $\begin{array}{l}\text { Carriers on enzyme } \\
\text { screening but no family } \\
\text { history }(n=3)\end{array}$ & 0 & 0 & 1 \\
\hline $\begin{array}{l}7 \\
2\end{array}$ & $\begin{array}{l}\text { TSD patients }\left(n=4^{*}\right) \\
\text { TSD fetus }(n=1)\end{array}$ & $\begin{array}{l}5 \\
1\end{array}$ & $\begin{array}{l}0 \\
0\end{array}$ & $\begin{array}{l}0 \\
0\end{array}$ \\
\hline Total 24 & 20 & 10 & 4 & 1 \\
\hline
\end{tabular}

* Each TSD patient has two unrelated chromosomes except for one whose parents are highly consanguineous and therefore represents one unrelated chromosome.

$16.6 \mathrm{mmol} / 1$ ammonium sulphate, $6.7 \mathrm{mmol} / 1$ magnesium chloride, $10 \mathrm{mmol} / \mathrm{l} \quad \beta$-mercaptoethanol, $170 \mu \mathrm{g} / \mathrm{ml}$ bovine serum albumin (Sigma)), $0.5 \mathrm{mmol} / \mathrm{l}$ dNTP (Pharmacia), $300 \mathrm{ng}$ of each primer, and 2.5 units Taq polymerase (Cetus). Taq polymerase was added after an initial denaturation step of $94^{\circ} \mathrm{C}$ for five minutes, followed by 30 cycles of 60 seconds at $93^{\circ} \mathrm{C}, 30$ seconds at $64^{\circ} \mathrm{C}, 90$ seconds at $72^{\circ} \mathrm{C}$ (plus an additional eight seconds per cycle); lastly the reaction was incubated at $72^{\circ} \mathrm{C}$ for five minutes to ensure complete polymerisation of all products. After purification with Geneclean II (Bio 101), the PCR products were subjected to the chemical mismatch method with osmium tetroxide and hydroxylamine. ${ }^{1415}$ The regions of mutation or polymorphism indicated by any mismatch bands were sequenced directly ${ }^{16}$ using the enzyme Sequenase (United States Biochemical Corporation).

The mutation detected using the chemical mismatch method (on PCR products amplified with primers $H$ ex $\alpha 8 \mathrm{~F}$ and $\mathrm{Hex} \alpha 10 \mathrm{R}$ ) was screened for by sequencing or restriction enzyme digestion since it fortuitously destroys a MaeII cutting site. Purified PCR products (amplified using the primers $\operatorname{Hex} \alpha 9 \mathrm{~F}$ and Hex $\alpha 10$ R) were digested with MaeII (Boehringer Mannheim Biochemica) in the buffer recommended by the manufacturer. Purified PCR products of a 736 base pair $(b p)$ section of the factor IX gene ${ }^{16}$ containing a control MaeII site were added to show whether digestion had been complete.

In order to determine effects of the mutation on mRNA, RNA extracted from fibroblasts of a TSD patient homozygous for the mutation and normal RNA was subjected to 'duplex' reverse transcription and PCR amplification. Two sets of primers were used, one set designed from the published HEXA gene cDNA sequence ${ }^{2}$ (HEX $\alpha 7 F$ and HEX $\left.\alpha b\right)$ and a second set designed from the published $\beta$ peptide (HEXB) gene cDNA sequence ${ }^{23}$ (HEX $\beta 8$ F and HEX $\beta$ b). Approximately 100, 200,400 , and $800 \mathrm{ng} \mathrm{RNA}$ were incubated with $50 \mathrm{ng}$ each of HEX $\alpha b$ and HEX $\beta b$ in a volume of $7.5 \mu \mathrm{l}$ at $65^{\circ} \mathrm{C}$ for 10 minutes and then transferred to an ice bath. Then 200 units Molony Murine Leukaemia Virus reverse transcriptase (RT) in RT buffer (both from Gibco-BRL) were added together with 25 units RNase inhibitor (Boehringer Mannheim Biochemica) and $0.025 \mathrm{mmol} / \mathrm{l} \mathrm{dNTP}$ (Pharmacia), to give a final volume of $20 \mu \mathrm{l}$. This mixture was incubated at $42^{\circ} \mathrm{C}$ for one hour then transferred to ice, after which $450 \mathrm{ng}$ each of primers $\mathrm{HEX} \alpha \mathrm{b}$ and $\mathrm{HEX} \beta \mathrm{b}$ and $500 \mathrm{ng}$ each of primers HEX $\alpha 7 \mathrm{~F}$ and $\mathrm{HEX} \beta 8 \mathrm{~F}$ were added. After heating to $94^{\circ} \mathrm{C}$ for five minutes, a premix containing 5 units $T a q$ polymerase and $5 \mu 110 \times$ PCR buffer (see above) were added to give a final volume of $50 \mu \mathrm{l}$. This mixture was then subjected to 23 cycles of PCR amplification, each cycle being one minute at $93^{\circ} \mathrm{C}$, one minute at $65^{\circ} \mathrm{C}$, and seven minutes at $72^{\circ} \mathrm{C}$, lastly followed by five minutes at $72^{\circ} \mathrm{C}$. Electrophoresis of $8 \mu \mathrm{l}$ of the reaction products was performed in a $1 \%$ agarose (Ultrapure, GibcoBRL) minigel with ethidium bromide. Reverse transcription and PCR amplification were also carried out with only one set of primers, specific for the HEXA gene (Hex $\alpha 6 \mathrm{~F}$ and Hex $\alpha 13 R)$. Approximately 200 to $300 \mathrm{ng}$ RNA, and 30 cycles of PCR amplification, were used.

SEQUENCES OF PRIMERS USED FOLLOWED BY CDNA NUCLEOTIDE POSITIONS

Amplification from genomic DNA:

Hex $\alpha 8 \mathrm{~F}: 5$ '-CTGGATTACTGACTCC-

TTGC-3' (812-821).

Hex $\alpha 9 \mathrm{~F}: 5^{\prime}$-GAAGTCCAACCCAGAGATCC-3' (987-1006).

Hex $\alpha 10 R: 5^{\prime}$-AACACCTCCTGCCACACCAC-3' (1130-1111).

Reverse transcription and PCR amplification from RNA:

Hex $\alpha 7 \mathrm{~F}: 5^{\prime}$-GTCACCCACATCTACACAGC-3' (688-707).

Hex $\alpha$ b: 5'-AAGGGGCTGCGTCCCCTGGC-3' (1679-1660).

Hexß8F: 5'-CAGAAAGACCTCCTGACTCC-3' (904-923).

Hexßb: 5'-TAGTACAGATTGCTGTGGCC-3' (1708-1689).

Hex $\alpha 6 \mathrm{~F}: 5^{\prime}$-TGGCATCTGGTAGATGATCC-3' (607-626).

Hex $\alpha 13 R: 5$ '-AGCAACTCACAGCGGAAGTG-3' (1523-1504).

\section{Results}

Twenty TSD carriers or patients from the UK and Eire, of no known Jewish ancestry (table 1), were screened for the mutations which predominate in the Jewish community; four had the more frequent mutation, a $4 \mathrm{bp}$ insertion into exon 11 , and one had the less frequent intron 12 donor splice site mutation. The remaining 15 carriers and patients were searched for unknown mutations; the results of chemical mismatch of a section of the HEXA gene spanning exon 8 to exon 10 in eight subjects (seven obligate TSD carriers, five UK and two Turkish, and one patient affected with juvenile onset TSD) are shown in fig 1. The larger mismatch band ( $>500 \mathrm{bp}$ ) appears, by virtue of its size, to be positioned well within an intron and therefore indicates a change which will not affect the coding sequence. The 


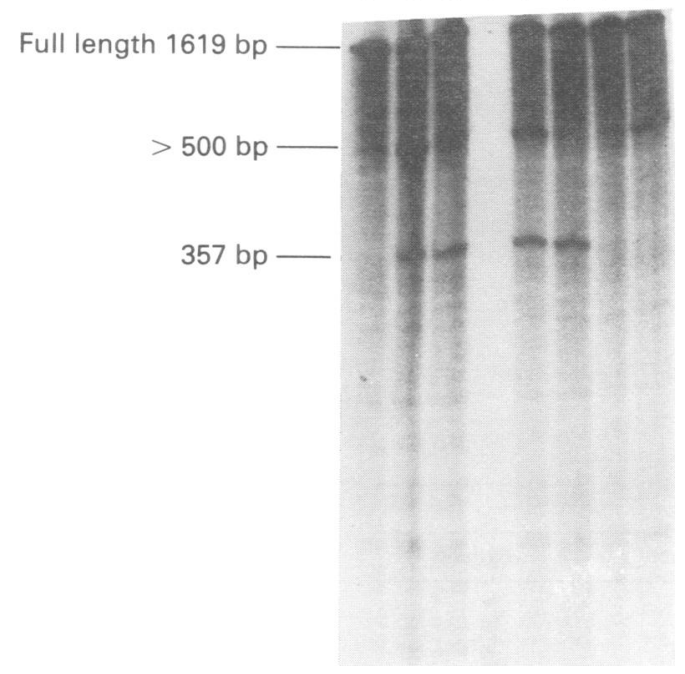

Figure 1 Chemical mismatch detection with hydroxylamine in a section of the HEXA gene spanning exons 8 to 10 . Lanes $1,2,3,4,6$ : parents of non- Fewish UK TSD patients; lane 5: juvenile onset UK TSD patient; lanes 7,8 : parents of Turkish TSD patient. (Lane 4 was lost; however this subject does show the $G$ to $A$ change in fig 2.).

region indicated by the $357 \mathrm{bp}$ mismatch band was sequenced in the same eight subjects (fig 2). The first base of intron 9 was changed from guanine $(G)$ to adenine $(A)$ in those patients who have the mismatch band. All five subjects shown in fig 2 to have the mutation were heterozygous for it since they also had the normal $G$ base at this position. The $G$ to $A$ mutation alters the obligatory GT of the intron 9 donor splice site. (The donor splice site is next to the $3^{\prime}$ end of an exon, and is essential for 'splicing out' of introns to form the mRNA.)

Nineteen unrelated mutant chromosomes from 15 UK or Eire TSD carriers and patients who were negative for the common 'Jewish' mutations were tested for the intron 9 donor splice site mutation using sequencing or digestion with MaeII restriction enzyme or both; 10 were found to be positive (table 1). The parents of four TSD patients included in table 1 were also tested for the intron 9 donor splice site mutation (table 2). Twenty-eight nonJewish controls and 12 Jewish carriers of other known mutations causing TSD were tested for the intron 9 splice site mutation; all were negative. Two Turkish TSD carriers were found to be negative for the intron 9 donor splice mutation (lanes 7 and 8 on figs 1 and 2).

The results of reverse transcription and PCR amplification of RNA are shown in fig 3. In 'duplex' reactions with two sets of primers (one set specific to the HEXA gene, the other specific to the HEXB gene), normal RNA (lanes 2 to 5 ) gives amplification products of the correct size from both the HEXA and HEXB genes. RNA from a TSD patient homozygous for the intron 9 splice site mutation (lanes 5 to 9 ) gives the correct size PCR product from the HEXB gene but no product has amplified from the HEXA gene. In reactions using one set of primers (specific to the
HEXA gene), RNA from a late infantile TSD patient negative for the intron 9 splice site mutation (lane 11) shows the correct size PCR product. In contrast, the PCR product of the TSD patient homozygous for the intron 9 mutation (lane 12) is barely visible.

\section{Discussion}

Over 20 mutations causing TSD have now been described (some reviewed by Neufeld ${ }^{11}$ ), most being of low frequency or confined to one family. The exceptions to this are mutations found at high frequency within genetically circumscribed populations such as the FrenchCanadians $^{45}$ and the Ashkenazi Jews. ${ }^{6-9}$ The intron 9 donor splice site mutation described in this study, which has also been detected by Akli et al,,$^{19}$ appears to be very frequent among non-Jewish TSD patients and carriers from the British Isles. Of 19 unrelated chromosomes which had already been shown not to carry either of the two common 'Jewish' mutations, $53 \%$ were found to be positive for the intron 9 donor splice site mutation. This was an unexpected result since the population studied is not a genetic isolate; carriers of the mutation include people of English, Scottish, Welsh, and Irish origin.

The nature of the mutation itself indicates that it is highly likely to be the cause of disease, since it is a change in the first nucleotide of intron 9, the donor splice site. Splice sites are known to have invariant sequence ${ }^{24}$ (GT) within their consensus sequence, any change leading to incorrect splicing of the mRNA and the production of aberrant, unstable mRNA species. ${ }^{25}$ This has already been shown to be the case for the intron 12 donor splice site mutation, ${ }^{26}$ causing TSD in the Ashkenazi Jewish community, an intron 5 donor splice site in a Tunisian TSD patient, ${ }^{27}$ and introns 2 and 4 donor splice site mutations in two French TSD patients. ${ }^{19}$

The $G$ to $A$ change in the first base of intron 9 is also unlikely to be a polymorphism since (1) it was not found in $28 \mathrm{UK}$ non-Jewish controls, (2) it was not found in 12 healthy Jewish carriers of known TSD mutations, and (3) if this change is simply a very frequent polymorphism then some non-TSD subjects could be expected to be homozygous; the only homozygotes found were two TSD patients (table 2). The G to A change has occurred at a $\mathrm{CpG}$ dinucleotide, frequent sites of mutation owing to spontaneous deamination of methylcytosine to thymidine. ${ }^{28}$ Since this is a G to $A$ change it must have arisen in the antisense strand (rather than the sense strand which would result in $\mathrm{C}$ to $\mathrm{T}$ ).

We would speculate that mutation of the intron 9 donor splice site would cause exon 9 to be lost during mRNA splicing. However, the coding sequence would continue to be in frame so that the protein produced would not be severely truncated but simply reduced by 29 amino acids (those coded for by exon 9). Preliminary studies using duplex reverse transcription and PCR amplification of RNA of a patient homozygous for the mutation showed 


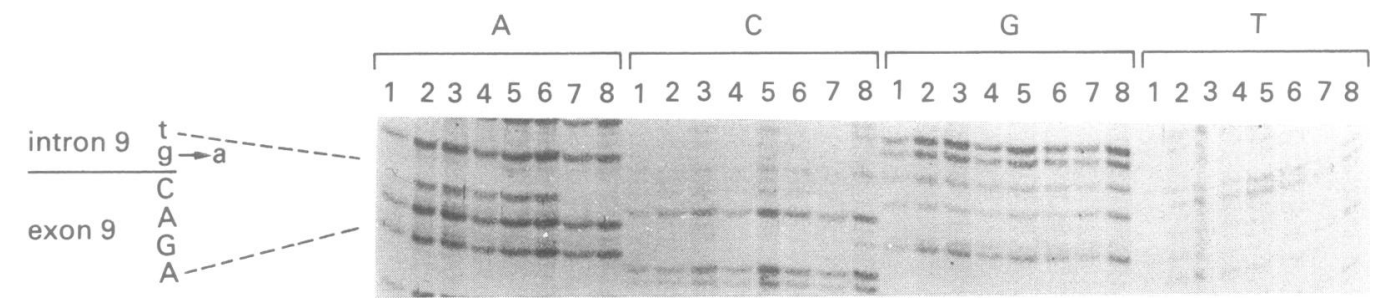

Figure 2 Genomic DNA sequence of region indicated by 357 bp mismatch band in fig 1. Lanes as in fig 1 .

Table 2 Intron 9 mutations in non-fewish TSD patients and parents.

\begin{tabular}{lccc}
\hline & \multicolumn{3}{c}{ Presence of intron 9 mutation } \\
\cline { 2 - 5 } & Mother & Father & Patient \\
\hline Patient 1 (infantile) & + & + & ++ \\
Patient 2 (infantile) & + & + & +- \\
Patient 3 (infantile) & + & NT & ++ \\
Patient 4 (juvenile) & + & - & +- \\
\hline
\end{tabular}

NT = not tested; however the parents of patient 3 are consanguineous.

\section{Duplex}

$\begin{array}{llllllll}1 & 2 & 3 & 4 & 5 & 6 & 7 & 8\end{array}$

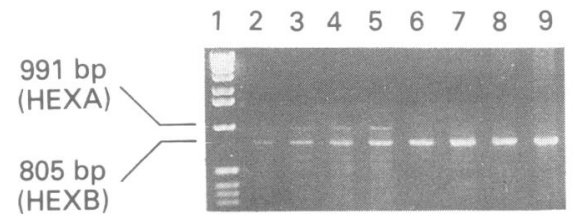

Figure 3 Reverse transcription and PCR amplification. Lanes 1-9: duplex reaction using $H E X A$ and $H E X B$ specific primers; lanes 10-12: reaction using only $H E X A$ specific primers. Lane 1: standard size marker; lanes 2-5: control normal $R N A$ (approximately 100, 200, 400, and $800 \mathrm{ng} R N A$ respectively); lanes 6-9: RNA of $T S D$ patient homozygous for the intron 9 donor splice mutation (approximately 100, 200, 400, and $800 \mathrm{ng} R \mathrm{R} A$ respectively); lane 10: standard size marker; lane 11: RNA of TSD patient negative for the intron 9 splice mutation; lane 12: RNA of TSD patient homozygous for the intron 9 splice mutation.

severe disruption of the splicing process; while a PCR product of the correct size amplified from the HEXB gene, no PCR product, of normal or reduced size, was obtained from the HEXA gene. Reverse transcription and PCR amplification using only one set of primers, specific for the HEXA gene (from exon 6 to exon 13), produced only a trace of normal sized product. It may be that incorrectly spliced mRNA species are formed but are unstable; further studies will be needed to determine precisely the effects of this mutation on HEXA mRNA splicing.

The high frequency of this mutation within a population of diverse origin indicates that it may be a very ancient mutation, or that it arose in a subgroup which has since mixed with the 'general population'. We tentatively suggest that this subgroup may have been of Celtic origin because the intron 9 splice site mutation was found at higher frequency in unrelated chromosomes of Irish, Scottish, or Welsh origin compared to English (63\% compared to $31 \%)$. There is already evidence that three different TSD mutations have reached a high frequency in two populations, the Ashkenazi Jews ${ }^{6-9}$ and the French-Canadians. ${ }^{45}$ The results of this study suggest that yet another different mutation at the same locus was also relatively frequent in a third population, before recent population admixture. If so, this may add force to the argument that some selective agent historically conferred a positive advantage on carriers of TSD mutations.

Of the 24 unrelated chromosomes tested in this study, the mutations of nine remain unknown; it will be interesting to see how many other mutations are present in the population. It seems unlikely that there will be one other very frequent mutation as in the Ashkenazim, as the population of the British Isles is very diverse in origin. The situation may resemble that of cystic fibrosis where there is one predominant mutation, $\Delta \mathrm{F} 508$, which accounts for approximately $74 \%$ of UK cystic fibrosis carriers, and several other rare mutations. $^{29}$

Carrier screening and prenatal diagnosis of Tay-Sachs disease can be done very effectively by enzyme assay of hex A. ${ }^{1}$ Rapid detection of new mutations causing TSD using PCR amplification, chemical mismatch, and sequencing will be useful in confirmation of borderline diagnoses and the development of preimplantation diagnosis. The present work shows that TSD families from the non-Jewish population of the British Isles should be screened for the intron 9 donor splice mutation, as well as the mutations which predominate in the Ashkenazi Jewish community, before more intense studies are undertaken to delineate their mutations.

We thank the British Tay-Sachs Foundation for generous financial support, Tina Slade for invaluable help with cell culture, and the many physicians who have sent us samples from their patients. The work of the Paediatric Research Unit is supported by the Generation Trust and the Spastics Society.

1 Sandhoff K, Conzelmann E, Neufeld E, Kaback M, Suzuki $K$. The $G_{M 2}$ gangliosidoses. In: Scriver CR, Beaudet $A L$, Sly WS, Valle D, eds. The metabolic basis of inherited disease. 6th ed. New York: McGraw-Hill, 1989:1807-42.

2 Myerowitz R, Piekarz R, Neufeld E, Shows TB, Suzuki K. Human $\beta$-hexosaminidase $\alpha$ chain: coding sequence and homology with the $\beta$-chain. Proc Natl Acad Sci USA 1985;82:7830-4.

3 Proia RL, Soravia E. Organisation of the gene encoding the human $\beta$-hexosaminidase $\alpha$-chain. I Biol Chem 1987;262:5677-81.

4 Myerowitz R, Hogikyan ND. A deletion involving Alu sequences in the $\beta$-hexosaminidase $\alpha$-chain gene of
French Canadians with Tay-Sachs disease. $\mathcal{F}$ Biol Chem 1987;262:15396-9.

5 Hechtman P, Kaplan F, Bayleran J, et al. More than one mutant allele causes infantile Tay-Sachs disease in mutant allele causes infantile Tay-Sachs disease in

French-Canadians. Am f Hum Genet 1990;47:815-22.
6 Myerowitz R, Costigan FC. The major defect in Ashkenazi Jews with Tay-Sachs disease is an insertion in the gene for Jews with Tay-Sachs disease is an insertion in the gene for
the $\alpha$-chain of $\beta$-hexosaminidase. $\mathcal{f}$ Biol Chem the $\alpha$-chain of

7 Myerowitz R. Splice junction mutation in some Ashkenazi Jews with Tay-Sachs disease: evidence against a single defect within this ethnic group. Proc Natl Acad Sci USA 1988;85:3955-9. 
8 Arpai E, Dunbrille-Ross A, Maler T, et al. Identification of an altered splice site in Ashkenazi Tay-Sachs disease. Nature 1988;333:85-6.

9 Ohno K, Suzuki K. A splicing defect due to an exon-intron junctional mutation results in abnormal $\beta$-hexosaminijunction $\alpha$ Tay-Sachs disease. Biochem Biophys Res Commun 1988;153:463-9.

10 Navon R, Proia RL. Tay-Sachs disease in Moroccan Jews: deletion of a phenylalanine in the $\alpha$-subunit of $\beta$-hexosadeletion of a phenylalanine in the $\alpha$-subunit of $\beta$-hexosa-

11 Neufeld E. Lysosomal storage diseases. Annu Rev Biochem $1991 ; 60: 257-80$

12 Landels EC, Ellis IH, Fensom AH, Green PM, Bobrow M. Frequency of the Tay-Sachs disease splice and insertion mutations in the UK Ashkenazi Jewish population. $f \mathrm{Med}$ Genet 1991;28:177-80.

13 Saiki RK, Gelfand DH, Stoffel S, et al. Primer-directed enzymatic amplification of DNA with a thermostable DNA polymerase. Science 1988;239:487-91.

14 Cotton RGH, Rodrigues NR, Campbell RD. Reactivity of cytosine and thymine in single-base pair mismatches with hydroxylamine and 0 hydroxylan to the study of mus:

15 Montandon AJ, Green PM, Gianelli F, Bentley DR. Direct detection of point mutations by mismatch analysis: appli-
cation to haemophilia B. Nucleic Acids Res 1989;17:334758.

16 Green PM, Bentley DR, Reuben SM, Nilsson IM, Gianelli F. Molecular pathology of haemophilia B. EMBO $\mathcal{f}$ 1989;8:1067-72.

17 Naylor JA, Green PM, Montandon AJ, Rizza CR, Gianelli F. Detection of three novel mutations in two haemophilia A patients by rapid screening of whole essential region of factor VIII gene. Lancet 1991;337:635-9.

18 Roberts RG, Montandon AJ, Bobrow M, Bentley DR. Detection of novel genetic markers by mismatch analysis. Nucleic Acids Res 1989;17:5961-71.
19 Akli S, Chelly J, Lacorte JM, Poenaru L, Kahn A. Seven novel Tay-Sachs disease mutations detected by chemical mismatch cleavage of PCR-amplified cDNA fragments. Genomics 1991;11:124-34.

20 Landels EC, Ellis IH, Bobrow M, Fensom AH. Tay-Sachs disease heterozygote detection: use of a centrifugal anayser for automation of hexosaminidase assays with two
different artificial substrates. $\mathcal{F}$ Med Genet 1991;28:101-9.

21 Sambrook J, Fritsch EF, Maniatis T. Molecular cloning; $a$ laboratory manual. 2nd ed. New York: Cold Spring Harlaboratory manual. 2nd ed. Nev

22 Chomczynski P, Sacchi N. Single-step method of RNA isolation by acid guanidinium thiocyanate-phenol-chloroform extraction. Anal Biochem 1987;162:156-9.

23 Neote K, Bapat B, Dumbrille-Ross A, et al. Characterization of the human HEXB gene encoding lysosomal $\beta$ hexosaminidase. Genomics 1988;3:279-86.

24 Shapiro MB, Senapathy P. RNA splice junctions of different classes of eukaryotes: sequence statistics and functional implications in gene expression. Nucleic Acids Res 1987;15:7155-74.

25 Treisman R, Orkin SH, Maniatis T. Specific transcription and RNA splicing defects in five cloned $\beta$-thalassaemia genes. Nature 1983;302:591-6.

26 Ohno $\mathrm{K}$, Suzuki K. Multiple abnormal $\beta$-hexosaminidase $\alpha$-chain mRNAs in a compound-heterozygous Ashkenazi Jewish patient with Tay-Sachs disease. $\mathcal{J}$ Biol Chem 1988;34:18563-7.

27 Akli S, Chelly J, Mezard C, Gandy S, Khan A, Poenaru L. $A$ " $G$ " to " $A$ " mutation at position -1 of a 5 ' splice site in a late infantile form of Tay-Sachs disease. $7 \mathrm{Biol}$ Chem 1990;265:7324-30.

28 Coulandre C, Miller JH, Farabaugh PJ, Gilbert W. Molecular basis of base substitution hotspots in $E$ coli. Nature 1978;274:775-80.

29 The Cystic Fibrosis Genetic Analysis Consortium. Worldwide survey of the dF508 mutation-report from the cystic fibrosis genetic analysis consortium. Am $\mathrm{f} \mathrm{Hum}$ Genet 1990;47:354-9. 